\title{
Comparison of the Amount of Escherichia Coli in Refilled Drinking Water at the Depot with Bottled Drinking Water
}

\author{
Frisca Ronauli Batubara', Dame Joyce Pohan', Dora Elysia Octavia Pasaribu ${ }^{3}$ \\ ${ }^{1,2,3}$ Faculty of Medicine, Universitas Kristen Indonesia, Jakarta
}

Corresponding Author: Frisca Ronauli Batubara

\begin{abstract}
Water needed for daily use is viable water that is clean and healthy. Due to limited access to clean water, people buy bottled water and refillable drinking water. It is necessary to do clinical research at the laboratory to determine whether the water condition is feasible or not for consumption. The purpose of this study was to determine whether or not there is E. coli bacteria in the refillable drinking water and bottled water. This study uses an experimental method. Samples were taken from 15 refillable drinking water depots in Kecamatan Rawalumbu Bekasi and 15 bottled water samples. The bacterias identification was made by planting the samples in Blood Agar media and EMB. The results showed four positive samples of $E$. coli bacteria (26.7\%) in the refillable drinking water depot at Kecamatan Rawalumbu Bekasi and one positive sample of $E$. coli bacteria $(6.7 \%)$ in bottled water. It was also found that other types of bacteria such as Coliform (6.7\%), Pseudomonas sp. (40\%), Klebsiella sp. (13.3\%), Staphylococcus sp. (6.7\%), and Streptobacillus Gram + (13.4\%).
\end{abstract}

Keywords: Refillable Drinking Water, Bottled Water, Escherichia coli.

\section{INTRODUCTION}

Water that humans need for daily needs is suitable for clean and healthy water. Water is a chemical compound that is very important for human life and other living things ${ }^{[1 ; 2]}$. Drinking water itself is water that has been processed or without treatment that meets health requirements and can be drunk directly ${ }^{[3]}$. The water supply system must meet several essential requirements. These requirements include physical requirements, chemical requirements, physical requirements and radiological requirements.

Based on Permenkes No.492 / Menkes / PER / IV / 2010, the requirements for clean water quality include physical, chemical, and microbiological requirements. The physical requirements are clear, odourless and tasteless. In addition, the temperature of clean water should be the same as the air temperature or approximately $250 \mathrm{C}$, and if there is a difference, the allowable limit is $25 \mathrm{oC} \pm$ $3 \mathrm{oC}$. Chemical requirements are not allowed to contain chemical substances in an amount that exceeds the limit, namely normal $\mathrm{pH}$, total solid, no organic substances such as aggressive $\mathrm{CO} 2$, hardness or high mineral content, calcium $(\mathrm{Ca})$, iron $(\mathrm{Fe})$, manganese $(\mathrm{Mn})$, copper $(\mathrm{Cu})$, zinc $(\mathrm{Zn})$, chloride $(\mathrm{Cl})$, nitrite, fluoride $(\mathrm{F})$, and heavy metals. Microbiological requirements, namely that it must not contain pathogenic and parasitic germs that interfere with health. This microbiological requirement is characterized by the absence of E. coli or Fecal Coli bacteria in the water ${ }^{[4]}$.

According to UNICEF, data shows that access to clean water in Indonesia in 2010 compared to 2007 decreased by approximately $7 \%$. Access to clean water in 
Jakarta has decreased from $63 \%$ in 2007 to $28 \%$ in $2010^{[5]}$. According to Beppenas 2012, access to drinking water sources in urban areas decreased from $49.82 \%$ in 2009 to $40.52 \%$ in 2011 . It tends to be due to the increasing use of bottled drinking water and refill drinking water as a source of drinking water. Based on Beppenas 2012 data, the use of bottled water and refill drinking water has increased from $10.35 \%$ in 2009 to $19.37 \%$ in 2010 . Due to limited access to clean water, people buy bottled drinking water and refill drinking water so that more and more refillable drinking water and bottled drinking water depots provide readyto-drink water. There is a high chance that this water can grow bacteria ${ }^{[6]}$.

According to the Decree of the Minister of Health No.492 / Menkes / PER / IV / 2010, one of the parameters for the quality of drinking water consumed is free from the Escherichia coli bacteria. 3 Escherichia coli itself is a Gram-negative bacteria in the form of a short rod with a length of about two $\mu \mathrm{m}$, diameter $0.7 \mu \mathrm{m}$, width $0.4-0.7 \mu \mathrm{m}$ and is facultatively anaerobic. E. coli forms colonies that are round, convex, and smooth with pronounced edges. E. coli is a member of the normal flora in the intestine but will be pathogenic or dangerous if the number of these bacteria in the digestive tract increases or is outside the intestine. E. coli produces enterotoxins which can cause diarrhoea ${ }^{[7]}$. The results of the 2003 Suprehin study showed that from 120 samples of drinking water in the refill depot obtained from 10 major cities, it was found that $16 \%$ were contaminated with coliform bacteria, one of which was Escherichia Coli and $60 \%$ of the samples examined did not meet at least one parameter of the SNI requirements. Thus, $2 / 3$ of the sample does not meet industry standards for bottled drinking water products. The ten big cities are Jakarta, Tangerang, Bekasi, Bogor, Cikampek, Denpasar, Yogyakarta, Semarang and Surabaya ${ }^{[8]}$.

From the description above, it is crucial to test the quality of drinking water produced from refill depots as well as bottled drinking water, and this must be done regularly to ensure the availability of safe and healthy drinking water for the community, given the increasing use of refilled drinking water and drinking water and bottled Drinking water to meet community needs. It is necessary because the people themselves cannot see the actual condition of whether refilled drinking water and bottled drinking water are consumed or not.

Research or clinical testing in the laboratory is needed to find out this condition. This study aims to identify the presence or absence of Escherichia coli bacteria in refilled drinking water from the depot and bottled drinking water in the Bekasi Rawalumbu sub-district based on the parameters set by the Minister of Health Regulation No. 492 of 2010 concerning requirements for the quality of drinking water. The problem answered in this study is "What is the ratio of Escherichia coli in drinking water refill depots in Rawalumbu District, Bekasi with bottled drinking water? To know the presence or absence of Escherichia coli in refill drinking water from a depot located in Rawalumbu District, Bekasi and bottled drinking water.

\section{LITERATURE REVIEW}

Based on the Regulation of the Minister of Health No.492 / Menkes / Per / IV / 2010, what is meant by drinking water is water that is processed or without any processing that meets health requirements and can be drunk directly ${ }^{[3]}$. The definition of drinking water can also be seen in the Decree of the Minister of Industry and Trade of the Republic of Indonesia No.651 / MPP / Kep / 10/2004, namely drinking water is raw water that has been processed and is safe for drinking [9]. Refillable drinking water is water that is produced through a purification process and does not have a brand. Meanwhile, refill drinking water depot is a business entity that manages drinking water for community needs in bulk and unpackaged ${ }^{[10]}$. Drinking 
water depot is an industrial business that processes raw water into drinking water and sells it directly to consumers. In principle, the water treatment process in drinking water depots is filtration (filtering) and disinfection. The filtration process is intended to separate suspended contaminants and separate the colloidshaped mixture, including microorganisms from the water, while disinfection is intended to kill microorganisms that were not filtered in the previous process ${ }^{[11]}$.

The tools used to process raw water into drinking water at refill drinking water depots are: a) Storage Tanks are helpful for storing raw water that can hold 3000 liters of water; b) Stainless Water Pump is helpful for pumping raw water from the storage tank into the filter tube; c) The filter tube has three functions, namely: 1) The first tube is an actives and filter media to filter coarse particles with materials from sand or other types that are effective with the same function; 2) The second tube is an anthracite filter which functions to remove turbidity with maximum and efficient results; c) The third tube is a granular active carbon filter media, which is a carbon filter that functions as an absorber of dust, taste, residual chlorine color and organic matter; d) Micro filter or water filter made of polyprophylene fiber which is used to filter water particles with a diameter of 10 microns, 5 microns, 1 micron and 0.4 microns with the intention of meeting drinking water requirements; e) Flow Meter is used to measure water flowing into refill gallons; f) Ultraviolet and ozone lamps are used for disinfection / sterilization of treated water; and g) Refill gallons are used as a place or container to store or store drinking water in it. Filling of the container is carried out using tools and machines and is carried out in a hygienic filling container ${ }^{[9]}$.

Definition of Bottled Drinking Water - Bottled drinking water is drinking water ready to be consumed directly without going through a healing process. In general, bottled drinking water can be grouped into gallons (19 litres) and small/single packs
${ }^{\text {[12] }}$. In the Decree of the Minister of Industry and Trade of the Republic of Indonesia No.651/MPP/Kep/10/2004 concerning technical requirements for the bottled drinking water industry and its trade, the primary raw material used is water taken from sources of guaranteed quality must be carried out to ensure water quality. Including a) Organoleptic, physical, chemical, microbiological and radioactive examinations; b) Sources of raw water must be protected from chemical and microbiological contamination which is damaging or disturbing to health. Bottled drinking water industrial companies must have documents regarding the development of the results of control and product quality testing following the applicable SNI, which are stored for a minimum of 2 (two) years. After obtaining the Indonesian National Standard, bottled drinking water must also register the product with the POM Agency for its feasibility assessment to be circulated in the market ${ }^{[8]}$.

Especially for Bottled Drinking Water products, the government has obliged all Bottled Drinking Water companies to have SNI 01- 3554-2015 and include the products as SNI marks prove that the company has SNI 01-3554-2015 certificate. It is following Kepmenperindag No.651 of $2004^{[12]}$. In order to obtain an SNI certificate, among other things must be done to meet the requirements. Requirements for obtaining SNI 01-3554-2015 are a) Administrative Requirements - Permit to take water from our own or a water supplier if we get water from another party. The raw water test results are according to Permenkes 907 of 2002 from our raw water or a water supplier if it gets water from other parties - NPWP, SIUP, TDP, TDI / IUI. - Brand certificate - Legal entity; and b) The company's technical equipment, laboratory equipment that must be available (can be replaced with other equipment according to product testing requirements), among others, turbidity meters, conductivity meters, ovens, $\mathrm{pH}$ meters, incubators, laboratory glass equipment, small digital 
scales, tests ozone, microbiological tools, and autoclaves.

All the equipment must have a calibration certificate by an accredited calibration body: a) Completeness and implementation of the Quality Management System Document covering; quality guidelines, procedures, work instructions, forms and quality records; b) Fill in the application form of the Indonesian National Standard, visit the Indonesian National Standard certification body that KAN has recognized; c) Fill out the company data form; d) MoU on cooperation contracts, rights and obligations of each, as well as costs. Drinking-Water Requirements - The requirements for drinking water quality can be broadly classified as follows:

Physical Requirements - Regulation of the Minister of Health of the Republic of Indonesia No. 492/Menkes/PER/IV/2010 concerning the quality of drinking water. It is stated that water that is fit for consumption in daily life is water with good quality as drinking water. It must meet the requirements physically, not smell, not tasteless, not cloudy, and colourless. In general, these physical requirements are considered for water aesthetics.

\section{Bacteriological Requirements -}

Water sources generally contain bacteria, both space water, surface water, and groundwater. The number and types of bacteria differ according to the place and conditions that affect them. Therefore, water consumed for daily purposes must be free from pathogenic bacteria. Bacteria of the Coli group (Coliform bacteria) are not pathogenic bacteria, but these bacteria are indicators of water contamination by pathogenic bacteria ${ }^{[14]}$. E. coli has long been recognized as an indicator of human faecal contamination in drinks or food. Some of the reasons why E. coli is cited as an indicator of contamination in faeces compared to other bacteria is ${ }^{[15]}$.

Chemical Requirements - Good drinking water is water that is not excessively polluted by chemical substances that are harmful to health, including
Mercury ( $\mathrm{Hg}$ ), Aluminum (Al), Iron (Fe), Fluoride (F), Cadmium (Cd), Manganese $(\mathrm{Mn})$, degree of acidity $(\mathrm{pH})$, and other chemical substances. The content of chemical substances in drinking water consumed daily should not exceed the maximum permissible levels as stated in the Regulation of the Minister of Health of the Republic of Indonesia No. 492/Menkes/PER/IV/2010 concerning requirements for drinking water quality ${ }^{[16]}$. The use of water that contains toxic chemicals and chemical substances that exceeds the maximum allowable levels will be bad for health and the materials used by humans. For example $\mathrm{pH}$; The $\mathrm{pH}$ of the water should be neutral, that is, not acidic and non-alkaline to prevent heavy metal leaching and tissue corrosion. The recommended water $\mathrm{pH}$ for drinking water is 6.5-8.5. Water is an excellent solvent, so if it is assisted by a $\mathrm{pH}$ that is not neutral, it can dissolve various chemical elements in its path ${ }^{[17]}$.

Benefits of Drinking Water for Health - Drinking water in the human body functions to balance metabolism and physiology. Every time, water needs to be consumed because every time the body is working and processing. In addition, water is also helpful in dissolving and processing food juices to be digested. The human body is made up of cells, and the most significant component of those cells is water. If there is a lack of water, the body's cells will shrink and not function properly ${ }^{[18 ; 19]}$. Escherichia coli - Escherichia coli is a commensal bacteria that can be pathogenic, acting as a significant cause of morbidity and mortality worldwide. Theodore Escherich first isolated Escherichia coli in 1885 from the faeces of a baby. E. coli is a Gram-negative bacterium in the form of a short rod with a length of about $2 \mu \mathrm{m}$, a diameter of $0.7 \mu \mathrm{m}$, a width of $0.4-0.7 \mu \mathrm{m}$ and is facultatively anaerobic. E. coli forms colonies that are round, convex, and smooth with pronounced edges ${ }^{[20 ; 21]}$. Escherichia coli is a type of mesophilic bacteria, namely bacteria whose optimum growth temperature is $15-45^{\circ} \mathrm{C}$ 
and can live at a $\mathrm{pH}$ of 5.5-8. According to research, E. coli has a maximum growth temperature of $40-45^{\circ} \mathrm{C}$, above which the bacteria will experience inactivation ${ }^{[22]}$.

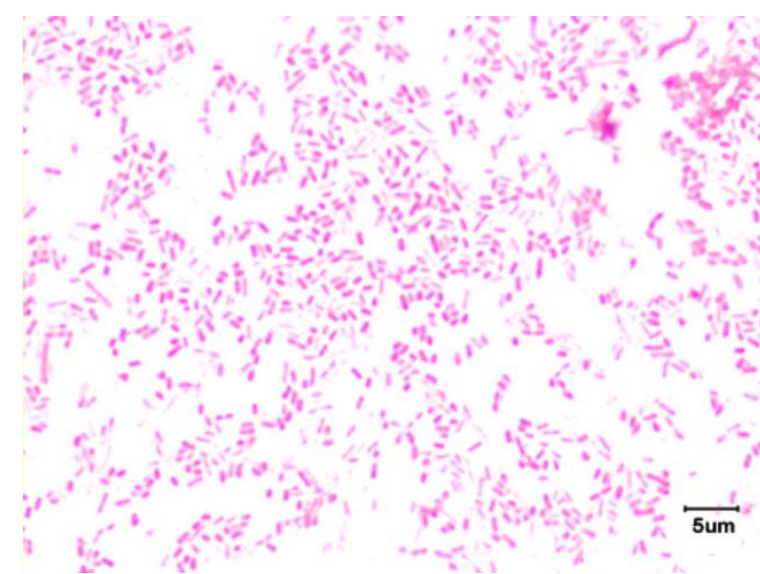

Figure 1. Escherichia coli with gram stain. Source: http://faculty.ccbcmd.edu/courses/bio141/lecguide/unit1/prostr uct/gnrod.html

E. coli Taxonomy - Based on its taxonomy E. coli is classified as follows; Kingdom: Prokaryotes; Division: Gracililicutes; Class: Scotobacteria; Order of Eubacteriales [23; 24; 25]; Family: Enterobacteriaceae; Genus: Escherichia; Species: Escherichia coli.7 Classification of E. coli - Based on nature and virulence characteristics, Escherichia coli is classified into four groups, namely: a) Enteroinvasive E. coli (EIEC) - Causes a disease similar to shigellosis by attacking intestinal mucosal epithelial cells; b) Enteropathogenic E. coli (EPEC) - Is a significant cause of diarrhoea in infants, especially in developing countries. These bacteria attach to the small intestine. EPEC infection can lead to watery diarrhoea that is difficult to treat and chronic; c) Enterotoxigenic E. coli (ETEC) Some ETEC strains produce exotoxins which are heat-labile (LT) and heat-stable toxins (ST). ETEC infection can cause symptoms of abdominal pain, sometimes accompanied by fever, vomiting, and blood in the stool; d) Enterohemorrhagic E. coli (EHEC) - E. coli serotypes that produce verotoxin, namely EHEC O157: H7. EHEC produces a toxin that has similar characteristics to the Shiga toxin produced by the Shigella dysenteriae strain. The verotoxin produced destroys the mucosal wall causing bleeding.

\section{RESEARCH METHOD}

This research is an experimental study by taking each sample of refill drinking water at the depot in the subdistrict of Rawalumbu Bekasi and bottled drinking water, then planting it on the Thioglycoat agar medium. After that, identification is to see and compare Escherichia Coli bacteria or not in refilled drinking water and bottled drinking water. This research was conducted at the Microbiology Laboratory of FK UKI from 27 October 2016 - 23 December 2016. The samples in this study were 15 refill drinking water depots located in the District of Rawalumbu Bekasi and 15 bottled drinking water. The research materials tested were refill drinking water samples taken from the depot in the Rawalumbu District of Bekasi and bottled drinking water. The research tools used in this study were $3 \mathrm{cc}$ syringes, Petri dishes, ose, colouring racks, test tubes, Bunsen flames and other tools commonly used in microbiology laboratories.

\section{RESULT AND DISCUSSION}

Table 1. Frequency distribution of Escherichia coli identification results in drinking water refill depots in Rawalumbu District, Bekasi.

\begin{tabular}{|l|l|l|}
\hline Germs & Number & $\mathbf{( \% )}$ \\
\hline E.coli & 4 & $26,7 \%$ \\
\hline Coliform & 1 & $6,7 \%$ \\
\hline Pseudomonas sp. & 6 & $40 \%$ \\
\hline Klebsiella sp. & 2 & $13,3 \%$ \\
\hline Staphylococcus sp. & 1 & $6,7 \%$ \\
\hline Streptobasil Gram $(+)$ & 1 & $6,7 \%$ \\
\hline Total & $\mathbf{1 5}$ & $\mathbf{1 0 0 \%}$ \\
\hline
\end{tabular}

A total of 15 samples of drinking water at the refill depot and 15 samples of bottled drinking water taken from the Rawalumbu District, Bekasi, were planted on blood agar media and EMB were then incubated. Examination of drinking water samples from the depot refill and bottled drinking water was carried out at the Microbiology Laboratory of the Faculty of Medicine, University of Indonesia. The results of this examination found germs which can be seen in the following table. 
Depot Refill Drinking Water - Based on table 4.1, Escherichia coli is positive as $26.7 \%$, while Escherichia coli is harmful as much as $73.3 \%$. However, in this negative E. coli result, other germs were identified.

Bottled Drinking Water - Based on table 4.2, data for Escherichia coli is positive as $6.7 \%$, while Escherichia coli is harmful as much as $93.3 \%$. In this negative E. coli result, another germ was identified, namely Streptobacillus Gram (+) and the rest of the sample was not overgrown with germs.

Table 2. Frequency distribution of Escherichia coli identification results in bottled drinking water in Rawalumbu District, Bekasi.

\begin{tabular}{|l|l|l|}
\hline Germs & Number & $(\mathbf{\%})$ \\
\hline E.coli & 1 & $6,7 \%$ \\
\hline Streptobasil Gram $(+)$ & 1 & $6,7 \%$ \\
\hline Not growing & 13 & $86,7 \%$ \\
\hline Total & $\mathbf{1 5}$ & $\mathbf{1 0 0 \%}$ \\
\hline
\end{tabular}

Based on the results of experimental research on the identification of Escherichia coli in drinking water refill depots and bottled drinking water, there were four samples of bottled drinking water contaminated by E. coli $(26.7 \%)$ and 11 samples of drinking water refill depots ( $73.3 \%$ ) were not contaminated with E. coli germs. However, in the depot refill drinking water sample, other germs were also found, namely Coliform, Pseudomonas sp., Klebsiella sp., Staphylococcus sp. And Streptobasil Gram (+). In bottled drinking water, 1 sample of drinking water contaminated by E. coli $(6.7 \%)$ and 14 samples of drinking water that was not contaminated by E. coli $(93.3 \%)$ was obtained, one of which was germ contamination others, namely Streptobacillus Gram (+) and the rest are not overgrown with germs. The presence of $\mathrm{E}$. coli in the refill depot drinking water samples in Rawalumbu District, Bekasi and bottled drinking water show that 15 samples of depot refill drinking water and one bottled drinking water sample do not meet the bacteriological requirements listed in the Permenkes RI Number 492 / MENKES / PER / IV / 2010. The number of E. coli in food and beverages must be $0 / \mathrm{g}$, or in other words, if only one E. colony is found in the drink sample, the drink does not meet health requirements ${ }^{[26]}$.

E. coli germ contamination in the drinking water refill depot and bottled drinking water can come from several sources. Namely the lack of clean and proper water sources used for washing utensils so that only use water collected in buckets and the workers in the depot for drinking water refill or bottled drinking water who do not wash their hands when processing the depot refill drinking water and bottled drinking water ${ }^{[27]}$. The environment and the presence of insects can also play a role as a factor for E. coli contamination. For example, flies can be a medium for the transfer (host) of microorganisms from the trash or sewer to the drinking water source. This research is in line with the research of Suprehin in 2003, which showed that out of 120 samples of drinking water refill depots obtained from 10 major cities, it was found that $16 \%$ were contaminated with Coliform bacteria, one of which was Escherichia coli and $60 \%$ of the samples examined did not meet at least one parameter of the SNI requirements. This study is also in line with Zulfikar's 2015 study, which showed that of the nine samples tested, only 1 sample was fit to drink while the other eight samples were not drinkable. Of the eight samples, five samples of E. coli were contaminated, while the other three samples contained Coliform and Pseudomonas sp.

\section{CONCLUSION}

Based on the results of research and data analysis, it can be concluded: a) From a total of 15 samples of drinking water refill depot in Rawalumbu District, Bekasi, four samples $(26.7 \%)$ were positive for E. coli; b) Meanwhile, from a total of 15 samples of bottled drinking water, 1 sample $(6.7 \%)$ was positive for E. coli. From these conclusions, several things can be suggested as follows:

For Refill Drinking Water Depot: a) Using state-of-the-art facilities and infrastructure to kill all types of germs; b) 
Directing workers to behave hygienically following the guidelines for the Implementation of Sanitation Hygiene for Drinking Water Depots; c) Avoiding the presence of mice, flies and cockroaches by improving the quality of environmental sanitation. Therefore it is advisable to keep the surrounding environment clean; d) Do not let garbage scatter. Garbage must be collected in a secure place and placed away from drinking water treatment plants; e) Improve the quality of drinking water products to meet the requirements contained in the Republic of Indonesia Minister of Health Regulation No.492 / Menkes / PER / IV / 2010.

For Bottled Drinking Water Companies: a) Complete operational standards (SOPs) related to processing bottled drinking water; b) It is also necessary to give strict sanctions for workers who do not carry out the SOP properly so that all workers are disciplined; c) Using state-ofthe-art facilities and infrastructure to ensure the hygienic level of drinking water; d) Perform regular laboratory tests to ensure that drinking water products are protected from all types of germs that can impact the health of consumers; e) Bottled drinking water companies actively and routinely conduct factory inspections. Sudden examinations; and f) Columns for consumer suggestions and complaints are also urgently needed so that bottled drinking water companies always provide the best products for the community.

For Bottled Drinking Water Industry Workers: a) Comply with all applicable SOPs in a disciplined manner; b) Using personal protective equipment (PPE), namely gloves, face masks, and hair covers to minimize contact with refill drinking water products so that the hygiene of drinking water is guaranteed; c) Always maintain the cleanliness of the environment to keep it clean and avoid the accumulation of waste and animals which can become a medium for spreading E. coli germs.

For the Bekasi City Health Office: a) There is a need for guidance and supervision of the management of refill drinking water depots by the City Health Office; b) Bekasi with a routine period and is carried out thoroughly to all refill drinking water depots in Bekasi City, so that the refill drinking water depot is more obedient in the implementation of guidance; c) Conducting warnings, withdrawing production products, and giving administrative sanctions to owners of refill drinking water depots that do not meet standards; d) Conducting counseling both for refill drinking water depot business actors and for the community as consumers of refill depot drinking water products and / or bottled drinking water about the importance of safe drinking water for health through the Puskesmas in accordance with their respective regions; and e) There is a need for affirmation by the Bekasi City Health Office in accordance with the authority in Permenkes No.492 / Menkes / Per / IV / 2010 concerning Requirements for Drinking Water Quality for refill drinking water depots.

For the Community: To all Indonesians, especially those who are consumers of bottled drinking water or drinking water from refill depots, the authors suggest that they raise awareness about drinking water hygiene, containing E. coli germs.

Acknowledgement: None

\section{Conflict of Interest: None}

\section{Source of Funding: None}

\section{Ethical Approval: Approved}

\section{REFERENCES}

1. Hossain, M. Z. (2015). Water: the most precious resource of our life. Global Journal of Advanced Research, 2(9), 1-11.

2. Boyd, C. E. (2019). Water quality: an introduction. Springer Nature.

3. Edition, F. (2011). Guidelines for drinkingwater quality. WHO chronicle, 38(4), 104108. 
4. Pachepsky, Y., Shelton, D., Dorner, S., \& Whelan, G. (2016). Can E. coli or thermotolerant coliform concentrations predict pathogen presence or prevalence in irrigation waters?. Critical reviews in microbiology, 42(3), 384-393.

5. Douglass, M. (2010). Globalization, megaprojects and the environment: Urban form and water in Jakarta. Environment and Urbanization Asia, 1(1), 45-65.

6. Nuria, M. C., Rosyid, A., \& Sumantri, S. (2009). Test of Escherichia Coli Bacteria in Refill Drinking Water from Refill Drinking Water Depot in Rembang Regency Testing of Escherichia Coli Bacteria Content in Drinking Water Refill From Drinking Water Refill Depot in Rembang Subdistrict. Mediagro, 5(1).

7. Sack, R. B. (2011). The discovery of cholera-like enterotoxins produced by Escherichia coli causing secretory diarrhoea in humans. The Indian journal of medical research, 133(2), 171.

8. Adriyani, R., \& Suprihatin, B. (2008). Hygiene Sanitation, Refillable Drinking Water Depot in Tanjung Redep District, Berau Regency, East Kalimantan. Jurnal Kesehatan Lingkungan Unair, 4(2), 3924.

9. Lepun, A. C. (2011). Implementation of Water Quality Monitoring at the Bogor City Area Refill Drinking Water Depot According to the Minister of Health Regulation Number 492 / MENKES / PER / IV / 2010 concerning Drinking Water Quality Requirements (Doctoral dissertation, Universitas Tarumanagara).

10. Hawkins, G., Potter, E., \& Race, K. (2015). Plastic water: The social and material life of bottled water. MIT Press.

11. Ghernaout, D., \& Elboughdiri, N. (2019). Electrocoagulation Process Intensification for Disinfecting Water- A Review. Applied Engineering, 3, 140-147.

12. Kiswanto, E. (2014). Consumer Protection Against the Negative Impact of Use of Refilled Drinking Water That Does Not Meet Quality Standards (Implementation Study of the Indonesian Minister of Health Regulation No. 492 / MENKES / PER / IV / 2010 concerning Drinking Water Quality Requirements). Kumpulan Jurnal Mahasiswa Fakultas Hukum.

13. Alwin Aprilian, M. (2019). Legal Protection for Refilled Drinking Water Consumers with the Application of the Permenkes No.
492 / Menkes / Per / Iv / 2010 Concerning The Quality Requirements Of Drinking Water (Doctoral dissertation, Universitas Muhammadiyah Jember).

14. Paruch, A. M., \& Mæhlum, T. (2012). Specific features of Escherichia coli that distinguish it from coliform and thermotolerant coliform bacteria and define it as the most accurate indicator of faecal contamination in the environment. Ecological Indicators, 23, 140-142.

15. Van Grieken, R., Marugán, J., Pablos, C., Furones, L., \& López, A. (2010). Comparison between the photocatalytic inactivation of Gram-positive E. faecalis and Gram-negative E. coli faecal contamination indicator microorganisms. Applied Catalysis B: Environmental, 100(12), 212-220.

16. Ministry of Health. (2010). Regulation of the Minister of Health of the Republic of Indonesia Number 492/MENKES/PER/IV/2010Ｒegarding Drinking Water Quality Requirements.

17. Li, P., Zhao, R., Chen, H., Wang, H., Wei, P., Huang, H., ... \& Sun, X. (2019). Recent advances in the development of water oxidation electrocatalysts at mild pH. Small, 15(13), 1805103.

18. Huff-Lonergan, E., \& Lonergan, S. M. (2005). Mechanisms of water-holding capacity of meat: The role of postmortem biochemical and structural changes. Meat science, 71(1), 194-204.

19. Batmanghelidj, F., \& Page, M. J. (2012). Your body's many cries for water. Tantor Audio.

20. Pal, S., Tak, Y. K., \& Song, J. M. (2007). Does the antibacterial activity of silver nanoparticles depend on the shape of the nanoparticle? A study of the gram-negative bacterium Escherichia coli. Applied and environmental microbiology, 73(6), 17121720.

21. Ge, X., Wang, R., Ma, J., Liu, Y., Ezemaduka, A. N., Chen, P. R., ... \& Chang, Z. (2014). DegP primarily functions as a protease for the biogenesis of $\beta$-barrel outer membrane proteins in the Gram- negative bacterium Escherichia coli. The FEBS journal, 281(4), 1226-1240.

22. Srivastava, A., Asahara, H., Zhang, M., Zhang, W., Liu, H., Cui, S., ... \& Chong, S. (2016). Reconstitution of protein translation of Mycobacterium reveals functional 
Frisca Ronauli Batubara et.al. Comparison of the amount of escherichia coli in refilled drinking water at the depot with bottled drinking water.

conservation and divergence with the gramnegative bacterium Escherichia coli. PLoS One, 11(8), e0162020.

23. Meier-Kolthoff, J. P., Hahnke, R. L., Petersen, J., Scheuner, C., Michael, V., Fiebig, A., ... \& Klenk, H. P. (2014). Complete genome sequence of DSM 30083 $\mathrm{T}$, the type strain (U5/41 T) of Escherichia coli, and a proposal for delineating subspecies in microbial taxonomy. Standards in genomic sciences, 9(1), 1-19.

24. Korf, I. H., Meier-Kolthoff, J. P., Adriaenssens, E. M., Kropinski, A. M., Nimtz, M., Rohde, M., ... \& Wittmann, J. (2019). Still something to discover: Novel insights into Escherichia coli phage diversity and taxonomy. Viruses, 11(5), 454.

25. Guo, A. C., Jewison, T., Wilson, M., Liu, Y., Knox, C., Djoumbou, Y., ... \& Wishart, D. S. (2012). ECMDB: the E. coli
Metabolome Database. Nucleic acids research, 41(D1), D625-D630.

26. Daud, M. K., Nafees, M., Ali, S., Rizwan, M., Bajwa, R. A., Shakoor, M. B., ... \& Zhu, S. J. (2017). Drinking water quality status and contamination in Pakistan. BioMed research international, 2017.

27. Nurlila, R. U., La Fua, J., Sahlan, L., \& Mallongi, A. (2019). Hygiene and Sanitation Management of Drinking Water Refill Depots for Feasibility Consumption in Kendari City, Indonesia. Indian Journal of Public Health Research \& Development, 10(8).

How to cite this article: Batubara FR, Pohan DJ, Pasaribu DEO. Comparison of the amount of escherichia coli in refilled drinking water at the depot with bottled drinking water. Int $J$ Health Sci Res. 2021; 11(5): 401-409. DOI: https://doi. org/10.52403/ijhsr.20210560 